\title{
Classification Management Research on Power Emergency Materials
}

\author{
Yan Tao Wang* and Jing Yan \\ School of Economics and Management, Northeast Dianli University, Jilin 132012, China \\ wangyantao@gmail.com
}

Keywords: Power emergency materials; Materials management; Materials reserves; Materials classification; Materials distribution

\begin{abstract}
Electric power enterprises urgently need to improve the ability of rapid response to resist risk and to provide more safe and reliable service for the national economy. Power emergency materials have many variety and quantity and their price is not the same. Besides, the inventory quantity is floating and uneven. Thus, the management of power emergency materials meets new challenge. The paper introduces the significance of power materials management and its type and ways of its reserve. The focus of this paper is the methods of reserves classification and implements the classifying management on power emergency materials to improve the level of power inventory management.
\end{abstract}

\section{Introduction}

The security and stability level of power grid around the nation have gradually increased. Therefore, natural disasters, primary and secondary equipment failure and weak local power grid are still the main factors threatening power grid. Recently power enterprises urgently need to solve the reserving problems to improve the ability of making rapid response to power emergency to resist risk and provide more safe and reliable service for the national economy. At present there is no unified planning and construction on power emergency materials within the state grid corporation. The construction level of reserves warehouse is lagging behind and unreasonable layout and the storage resource is large wasted and its service ability is low efficiency. According to the developing strategy proposed by the state grid company, it is necessary to strengthen the management of power emergency materials and quickly construct the emergency system of power materials.

\section{Significance of Power Emergency Materials Reserves Management}

Emergency materials management is an important part of materials management. Materials reserve is the foundation and the guarantee of smoothing the process of power emergency rescue. It also directly affects the response speed and final effects of power emergency rescue. The effective emergency materials reserve can greatly compress the time interval from emergency occurring to solving problem. Abundant reserve quantity and reasonable reserve structure of emergency materials are conducive to make full use of limited human, materials and financial resources to improve the efficiency of power emergency rescue and minimize the power emergency damages. Materials management of power emergency needs to evaluate the risk of all kinds of emergencies and optimize the storage schemes of power emergency materials.

To study on reserves management of power emergency materials can optimize the allocation of 
the storage resources and improve the materials' turnover and thus, the cost of warehouse can be reduced. When incident occurs, it is necessary to scientifically analyze the demand of emergency materials according to the characteristics of each incident. Deployment strategy of rapid response for emergency logistics should be put forward to quickly make a mobilization plan of allocating emergency materials.

\section{Classifications and Reserve Ways of Power Emergency Materials}

The definition of emergency materials by state grid corporation is the reserved materials needed to recover power outage in short time. When power breakdowns and emergency response mechanism starts the emergency materials will be put to use and delivered to the scene of the accident.

Through years of management experience people realize the importance of power emergency materials and enrich its connotation constantly. It concludes not only equipments of emergency materials and emergency relief materials but also inventory materials, materials under construction, stock materials of suppliers and urgency procurement. The classification of all kinds of power emergency materials is summarized in table 1 below.

Table 1 Classification of power emergency materials

\begin{tabular}{|l|l|}
\hline \multicolumn{1}{|c|}{ Classification of Materials } & \multicolumn{1}{|c|}{ Definition and Scope } \\
\hline Inventory Materials & $\begin{array}{l}\text { Inventory materials refer to the materials reserved in the storages } \\
\text { for power repair. It includes transformers, equipments of relay } \\
\text { protection, power cables, aluminum wires, electrical products } \\
\text { electrical instrumentation and generators, etc. }\end{array}$ \\
\hline Materials under Construction & $\begin{array}{l}\text { It refers to the materials under projects construction. It includes } \\
\text { infrastructure, technical renovation, repairs and so on. }\end{array}$ \\
\hline Inventory Muterials of & $\begin{array}{l}\text { Under reserve agreement the materials are not stored in the } \\
\text { power companies but in the garages of suppliers. }\end{array}$ \\
\hline Urgency Procurement & $\begin{array}{l}\text { When emergency occurs the materials are purchased urgently to } \\
\text { smooth the completion of the emergency response. }\end{array}$ \\
\hline Emergency Equipments & $\begin{array}{l}\text { Emergency equipments are related equipments that meet the } \\
\text { needs of all kinds of urgent repair and ensure the demands of } \\
\text { power supply, such as, communication equipment, kitchen, } \\
\text { lifting equipment, jack, rubber boats, working lamp, etc. }\end{array}$ \\
\hline Emergency Relief Materials & $\begin{array}{l}\text { It refers to the materials that meet the needs of various power } \\
\text { emergency and disaster relief. It may includes life detector, } \\
\text { cotton tents, sleeping bags, beddings, medicine, tents, } \\
\text { prefabricated houses, safety protective equipments, etc. }\end{array}$ \\
\hline
\end{tabular}

According to the characteristics of different materials different ways of reserve should be adopted. They are mainly physical reserve, united reserve and dynamic reserve. It is shown in table 2.

\section{Classification Reserves Methods of Power Emergency Materials}

Power emergency materials have some special characteristics. They are various goods, different specifications, large value gap, and different demand degree and quantity and reserve ways. Thus the power emergency materials should be managed by classification. According to the amount of materials reserve and emergency demand by scientifically analyzed the power emergency materials 
should be reserved by their nature and demand quantity. On the basis of analysis of characteristics the materials can be hierarchically classified to reduce inventory cost and improve the economic benefit. The methods of hierarchic classification are fuzzy clustering analysis, fuzzy comprehensive evaluation, analytic hierarchy process, and $\mathrm{ABC}$ management. At present there are less application of hierarchical classification for power emergency materials.

Table 2 Reserve ways of power emergency materials

\begin{tabular}{|l|l|}
\hline Reserve Ways & \multicolumn{1}{c|}{ Definition and Scope } \\
\hline Physical Reserve & $\begin{array}{l}\text { Physical reserve is the most common way of reserve. It means that after } \\
\text { purchasing the materials are stored directly in the power companies' internal } \\
\text { warehouses. Materials reserved by this way are managed by the internal } \\
\text { regulation of companies' management, such as regular taking stock, } \\
\text { maintenance, repair and replacement. }\end{array}$ \\
\hline United Reserve & $\begin{array}{l}\text { It is a new way of reserve that establishes agreements with suppliers to put } \\
\text { some emergency materials in the materials' warehouses for storage. It is } \\
\text { suitable for materials of large size, high value or difficult maintenance. Put } \\
\text { these goods in the suppliers'garages can reduce the storage cost effectively. }\end{array}$ \\
\hline Dynamic Reserve & $\begin{array}{l}\text { In the progress of engineering construction and overhaul technological } \\
\text { upgrading the spare parts of production and emergency apparatus are } \\
\text { dynamically used. This way of reserve is more reasonable for those materials } \\
\text { that are of easy loss, low value, good provision for produce, such as cable } \\
\text { wire and join hardware and so on. }\end{array}$ \\
\hline
\end{tabular}

Fuzzy Clustering Analysis Method. The basic idea of cluster analysis is to use similarity scale to measure the closeness degree between things and to realize classification. A class is a collection of some similar objects. The essence of the fuzzy clustering analysis is to construct the fuzzy matrix based on the study of the attributes of the object itself and on this basis to determine the classification relationship according to certain membership. When some samples are divided into unclear type and number this method can obtain ideal effect.

Fuzzy Comprehensive Evaluation Method. Comprehensive evaluation is to make a general evaluation on things or object which is restricted by various factors and can not be described by precise language. To evaluation the quality of power emergency materials belongs to this comprehensive evaluation. Things that are evaluated from various perspectives inevitably has fuzziness and subjectivity. Thus the evaluation results of fuzzy mathematics comprehensive should be more objective as far as possible to achieve better effect.

Analytic Hierarchy Process Method. Analytic hierarchy process was put forward in the 1970s by Thomas L. Saaty, a mathematic and operations professor. Its basic idea is to decompose the complex problem into hierarchical structure and then to make pairwise comparison between the next level and the upper level of various factors to construct judgment matrix. Through calculation on judgment matrix the next job is to make hierarchical sorting and consistency inspection and finally make hierarchy total sorts to get the combination weights of all factors. Last through the sorting result the problems are analyzed and solved.

The method of analytic hierarchy process has the advantage of low demand of information and short time of decision-making process. It is a combination of qualitative analysis and quantitative analysis. It is also a systematic and hierarchical method and is of high logicalization, simplicity and practicability. It quantified the policymakers' experience and can avoid errors of logic reasoning 
when the structure is complicated and schemes are a lot. It is especially suitable for those hard to make quantitative analysis on complicated problem. And in general, applicating the analytic hierarchy process to determine weight of factors should follow the following steps.

The first step is to analyze problems and establish the hierarchy model. The second step is to construct judgment matrix. The third is to make weight calculation of all matrixes. The last one is to get total hierarchy and check the consistency. Among them, the determination of evaluation index and the weight proportion of each evaluation index are two key links.

ABC Classification Method. ABC classification is a classification method on enterprises' materials based on the principle of "two to eight". It is also known as the emphasis management and is a common method used by enterprises to manage inventory. Its basic thought is to grasping the principal of things and carry on the corresponding management. It can reduce management costs and improve enterprise efficiency. According to each material's proportion to the total inventory capital and the proportion to the total number of varieties the inventory materials are divided into three levels of class A, class B and class C. Inventory of class A has small quantity but larger occupation of funds. Inventory of class B stocks generally important materials. Inventory materials of class $\mathrm{C}$ are relatively unimportant. Management and control on materials should be discriminating respectively according to different classification level. As shown in table $3, \mathrm{ABC}$ classification has the advantage of simple operation and is able to manage and control inventory combining with emphasis and common. So the method of ABC classification on inventory management of power emergency materials has a lot of deficiencies and limitations.

Table 3 ABC Classification List

\begin{tabular}{|c|c|c|l|}
\hline Classification & $\begin{array}{c}\text { Occupation Rate } \\
\text { of Variety(\%) }\end{array}$ & $\begin{array}{c}\text { Occupation of } \\
\text { Funds(\%) }\end{array}$ & Management Style \\
\hline A & $5-20$ & $60-70$ & Importance management and control \\
\hline B & $20-30$ & $10-20$ & General management and control \\
\hline C & $60-70$ & $5-10$ & Simple and convenient control \\
\hline
\end{tabular}

The comparison of the four kinds of classification methods is shown in table 4 .

Table 4 Comparison of Classification Methods on Power Emergency Materials

\begin{tabular}{|l|l|l|}
\hline \multicolumn{1}{|c|}{ Method } & \multicolumn{1}{|c|}{ Characteristic } & \multicolumn{1}{c|}{ Application } \\
\hline $\begin{array}{l}\text { Fuzzy Clustering } \\
\text { Analysis }\end{array}$ & $\begin{array}{l}\text { Researching statistics and the } \\
\text { similarity of things }\end{array}$ & $\begin{array}{l}\text { It needs big sample size and the type and } \\
\text { the quantity of the given sample is not } \\
\text { known. }\end{array}$ \\
\hline $\begin{array}{l}\text { Fuzzy } \\
\text { Evaluation }\end{array}$ & $\begin{array}{l}\text { Making a general evaluation } \\
\text { about the received materials } \\
\text { being restricted by factors }\end{array}$ & $\begin{array}{l}\text { Evaluation involves fuzzy factors and the } \\
\text { type and the quantity of classification to be } \\
\text { divided are known. }\end{array}$ \\
\hline $\begin{array}{l}\text { Analytic Hierarchy } \\
\text { Process }\end{array}$ & $\begin{array}{l}\text { Combining the qualitative } \\
\text { and quantitative analysis and } \\
\text { decomposing } \\
\text { problems step by step }\end{array}$ & $\begin{array}{l}\text { complex structure is relatively complex and the } \\
\text { decision criterions are more and the } \\
\text { classification are not easy to be quantized. }\end{array}$ \\
\hline ABC Classification & $\begin{array}{l}\text { Key management and simple } \\
\text { method and being widely } \\
\text { used }\end{array}$ & $\begin{array}{l}\text { for the classification of enterprises' } \\
\text { materials the importance of materials is } \\
\text { mainly composed by its percentage of } \\
\text { funds and quantity. }\end{array}$ \\
\hline
\end{tabular}




\section{Conclusion}

This paper studies on the demand and reserve of the power emergency materials. Considering the speciality of power companies the classification system of power emergency materials should be set according to production, procurement, demand and reservation. The paper argues four classification methods and thus power emergency materials should be reserved and managed by the reasonable and suitable classification method. Through analyzing the data of materials the reserve mode can be determined. Finally, the regulation of reservation management on power emergency materials can be set well. Modern logistics inventory management can improve the management level of power emergency materials and finally get good rescue efficiency.

\section{References}

[1] Taskin S, Lodree Jr E J. Inventory decisions for emergency materials based on hurricane count predictions [J]. International Journal of Production Economics, 2010, 126(1): 66-75.

[2] Emadi A, Nasiri A, Bekiarov S B. Uninterruptible power materials and active filters[M]. CRC press, 2004, 19-31.

[3] Yongda Guo, Hao Zhang, Fei Chou. Emergency Guarantee System of Shanghai Power Company[J]. Management and Operation, 2011, (3): 81-82.

[4] Zhifa Wang. Study on Emergency Materials of Power Company[J]. Logistics Project and Management. 2012, 34(8): 81-83.

[5] Jingfu Shang, Yu Zhang, Jianhua Zhang. Management System Design of United Reserve of Power Emergency Materials[J]. Power Technical Economy, 2010, (6): 57-65.

[6] Richardson D M, Rupp V A, Long K R, et al. Using Lean Methodology to Decrease Wasted RN Time in Seeking Materials in Emergency Departments[J]. Journal of Nursing Administration, 2014, 44(11): 606-611.

[7] Tian J, Ma W, WANG Y, et al. Emergency materials distributing and vehicle routes programming based on particle swarm optimization[J]. Systems Engineering-Theory \& Practice, 2011, 5: 16-19.

[8] Wenjuan Yang. Reservation Study on District Emergency Materials[D]. Beijing: Beijing University of Communications, 2009: 6-10.

[9] Motapon S N, Dessaint L A, Al-Haddad K. A Comparative Study of Energy Management Schemes for a Fuel-Cell Hybrid Emergency Power System of More-Electric Aircraft[J]. Industrial Electronics, IEEE Transactions on, 2014, 61(3): 1320-1334.

[10] Mohammadi R, Ghomi S M T F, Zeinali F. A new hybrid evolutionary based RBF networks method for forecasting time series: A case study of forecasting emergency supply demand time series[J]. Engineering Applications of Artificial Intelligence, 2014, 36: 204-214. 